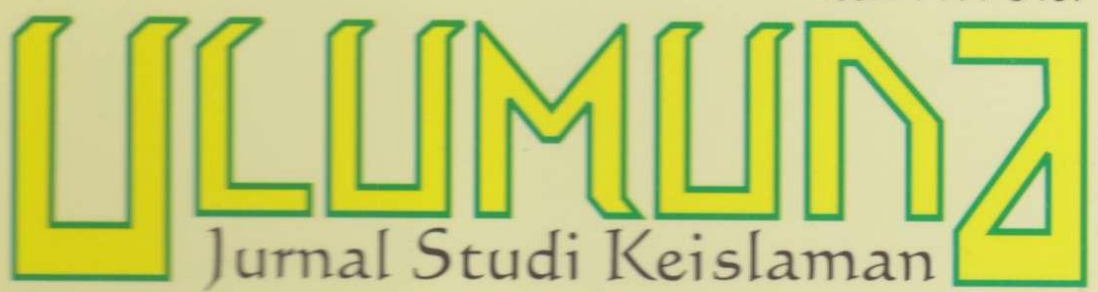

Volume 16 • Nomor 2• Desember 2012

Terakreditası B; SK Dirjen Dikti Kemdikbud Nomor: 56/DIKTI/Kep/2012, Tanggal 24 Juli 2012

REORIENTASI KAJIAN TEOLOGI ISLAM: IKHTIAR KONTRIBUTIF ATASI PROBLEM KEKINIAN Muhammad Rusli

PERGOLAKAN TEOLOGI SYIAH-SUNNI: MEMBEDAH POTENSI INTEGRASI DAN DISINTEGRASI

Slamet Mulyono MEnimbang KontorVERSI PEMAKNAAN KONSEP AHL AL-KITĀB DALAM AL-QUR'AN Zulyadain ECOTHEOLOGY:

TEOLOGI KONSTRUKTIF ATASI KRISIS LINGKUNGAN Abdul Quddus AKU DALAM TUHAN: IMPLIKASI TEOLOGI PROSES PADA ERA KONTEMPORER Suhermanto la'far PERgulatan TEOLOGI SALAFI DALAM MAINSTREAM KEBERAGAMAAN MASYARAKAT SASAK Faizah STUDI KOMPARATIF KONSEP KETUHANAN ISLAM DAN AGAMA ADAM PADA KOMUNITAS SAMIN Mohammad Rosyid KEGALAUAN IDENTITAS:

Dilema Hubungan Komunitas Muslim dan Hindu di BalI Siti Raudhatul Jannah 



\section{DAFTAR ISI}

\section{Pedoman Transliterasi}

\section{3-244 • Muhammad Rusli,}

"Reorientasi Kajian Teologi Islam:

Ikhtiar Kontributif Atasi Problem Kekinian"

245-278 • Slamet Mulyono,

"Pergolakan Teologi Syiah-Sunni:

Membedah Potensi Integrasi dan Disintegrasi"

279-310 • Zulyadain,

"Menimbang Kontorversi Pemaknaan

Konsep Ahl Al-Kitāb Dalam Al-Qur'an"

311-346 • Abdul Quddus,

"Ecotheology:

Teologi Konstruktif Atasi Krisis Lingkungan"

347-374 • Suhermanto Ja'far,

"Aku dalam Tuhan:

Implikasi Teologi Proses pada Era Kontemporer”

375-402 • Faizah,

"Pergulatan Teologi Salafi

dalam Mainstream Keberagamaan Masyarakat Sasak"

403-442 • Mohammad Rosyid,

"Studi Komparatif Konsep Ketuhanan Islam

dan Agama Adam pada Komunitas Samin"

443-464 • Siti Raudhatul Jannah,

"Kegalauan Identitas: Dilema Hubungan

Komunitas Muslim dan Hindu di Bali”

\section{INDEKS}

APENDIKS 


\section{PEDOMAN TRANSLITERASI}

\begin{tabular}{|c|c|c|c|c|c|c|}
\hline 1 & $=$ & $\mathbf{a}$ & & $\dot{\varepsilon}$ & $=$ & $\mathrm{g}$ \\
\hline ب & $=$ & b & & ف & $=$ & f \\
\hline$ت$ & $=$ & $\mathbf{t}$ & & ق & $=$ & $q$ \\
\hline$\dot{H}$ & $=$ & th & & ك & $=$ & $\mathbf{k}$ \\
\hline ج & $=$ & $\mathbf{j}$ & & J & $=$ & 1 \\
\hline$\tau$ & $=$ & ḥ & & s & $=$ & $\mathrm{m}$ \\
\hline$\dot{\tau}$ & $=$ & $\mathbf{k h}$ & & $\dot{ن}$ & $=$ & $\mathbf{n}$ \\
\hline$د$ & $=$ & d & & 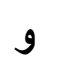 & $=$ & $\mathbf{w}$ \\
\hline$\dot{j}$ & $=$ & dh & & ○ & $=$ & $\mathbf{h}$ \\
\hline$\jmath$ & $=$ & $\mathbf{r}$ & & $\varepsilon$ & $=$ & , \\
\hline j & $=$ & $\mathbf{z}$ & & ي & $=$ & $\mathbf{y}$ \\
\hline س س & $=$ & s & & & & \\
\hline 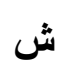 & $=$ & sh & \multicolumn{4}{|c|}{ Untuk Madd dan Diftong } \\
\hline ص - ص & $=$ & ș & i & $=$ & \multicolumn{2}{|c|}{$\bar{a}$ (a panjang) } \\
\hline ض ض & $=$ & d & إي & $=$ & \multicolumn{2}{|c|}{$\overline{1}$ (i panjang) } \\
\hline b & $=$ & $t$ & أو & $=$ & \multicolumn{2}{|c|}{ ù (u panjang) } \\
\hline ظ & $=$ & z & او & $=$ & \multicolumn{2}{|c|}{ aw } \\
\hline$\varepsilon$ & $=$ & ' & أي & $=$ & \multicolumn{2}{|l|}{ ay } \\
\hline
\end{tabular}

Contoh penulisan dengan transliterasi:

اعوذ بالله من الشيطان الرجيم (a'üdhu bi al-Lāh min al-shaytān al-rajīm);

بسم الله الرحمن الحيم النمن الثيط (bism al-Läh al-rahmān al-rahìm);

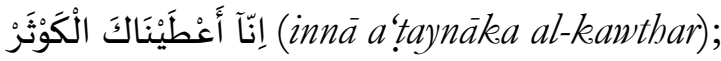

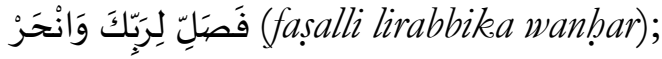

صباح الخير (sabāh al-khayr). 


\title{
AKU DALAM TUHAN: \\ IMPLIKASI TEOLOGI PROSES \\ PADA ERA KONTEMPORER
}

\author{
Suhermanto Ja'far \\ (IAIN Sunan Ampel Surabaya \\ Email: suhermanto.jafar@gmail.com)
}

Abstract: Theological implications in social lives are still worth analyzed. This paper discusses the authentic image of man as I in the relationship with God and the world. These relationships affect the nature of the world and the world to change the nature of God. The implications of the inclusion of God in the world is God's presence to the world and the world is affected God. Immanent God is the God who is present in every human being, every living being, and the universe. Every human being is unique and as I am in the uniqueness of God is present. In the directionality that God wanted man and the world become "like Him", they are united with him; He is involved in the principles and ways of working people and the world. Even though God is in everything and everything is in God, it does not mean that everything is identical, or equal with God. God that is "above" and present "in" the world to make people as I was in the Lord

Abstrak: Implikasi-implikasi teologis pada kehidupan masib relevan didiskusikan. Tulisan ini membahas tentang citra manusia otentik sebagai Aku dalam relasinya dengan Tuhan dan dunia. Relasi ini mempengarubi watak dunia dan dunia mengubah sifat Tuhan. Implikasi dari penyertaan Tuhan pada dunia adalab Tuban yang hadir ke dunia dan dunia dipengarubi Tuban. Tuban dipandang sebagai Yang Imanen, yang hadir dalam diri setiap manusia, setiap makhluk hidup, dan dalam alam semesta. Setiap manusia sebagai Aku adalah unik dan dalam kunikan tersebut Tuban hadir. Dalam keterarahan itu Tuhan menghendaki manusia dan dunia menjadi "seperti Dia" bersatu dengan-nya; Dia terlibat dalam prinsip dan cara kerja manusia dan dunia. Sekalipun Tuban ada dalam segala sesuatu dan segala sesuatu ada dalam Tuban, itu tidak berarti bahwa segala sesuatu itu identik, atau sama dengan Tuban. Tuban yang ada "di atas" dan hadir "di dalam" dunia menjadikean manusia sebagai Aku berada dalam Tuban

Keywords: Tuhan, manusia, teologi proses, imanensi, transendensi. 
PENGALAMAN terpenting bagi seseorang dalam hidupnya adalah ketika seorang manusia benar-benar menjadi konkret. Manusia konkret, yaitu aku merupakan pembahasan yang menonjol dalam filsafat modern. Ini karena manusia merupakan inti dari keseluruhan sistem pemikiran, baik menyangkut, kesadaran, pengetahuan maupun perilakunya. Manusia merenung tentang dirinya (aku) untuk mengungkap tentang ciri khas pribadinya. Aku dapat dimengerti sebagai sebuah kesadaran diri, karena manusia dengan akunya hadir untuk dirinya sendiri. Manusia atau aku sadar bahwa dirinya ada dan mengalami apa-apa yang terjadi, di luar maupun di dalam kehidupan pribadinya.

Manusia adalah tubub dan mempunyai tubuh, sehingga istilah yang tepat adalah kebertububan yaitu manusia mempunyai sekaligus adalah tubuhnya itu sendiri. Relasi kebertubuhan manusia dengan roh dikenal dengan istilah subjective incarnece, yaitu subyek atau aku sebagai roh yang terjelmakan ke dalam tubuh. Di sinilah roh sebagai subyek mendapatkan sarana atau media mengekspresikan aspek rohaninya melalui tubuh. Isi aku yang berupa pikiran, perasaan, keinginan, dan suasana batin lainnya tetap tertinggal dan tersembunyi bagi orang lain, kecuali kalau aku menyatakan dengan tubuh. Karena itu, tubuh merupakan sarana kontak yang amat penting.

Kebertubuhan sebagai sarana kontak keterbukaan manusia atau aku ke luar dirinya, setidak-tidaknya ada tiga keterbukaan manusia terhadap realitas di luar dirinya, yaitu keterbukaan manusia dengan dunia, keterbukaan dengan sesama, dan keterbukaan manusia dengan Tuhan. Pertama, Keterbukaan manusia dengan dunia merupakan suatu hal yang amat mendasar, sebab manusia hidup dalam dunia, sehingga manusia hadir menjadi barang dunia. Karena itu, manusia hidup dalam dunia berarti manusia harus ada dalam dunia sebagai barang dunia. Dunia dan manusia terjalin sinergis, sehingga tanpa adanya keterjalinan itu tidak dapat dipikirkan dan tidak ada manusia. Relevan sekali ucapan Martin Heidegger yang memakai rumusan being in the world (ada-dalam-dunia) untuk mencirikan hidup manusia.

Being in the world sebagai ciri hidup manusia, maka manusia berada dalam situasi sehingga manusia benar-benar hidup secara 
konkret dalam dunia. Hidup dalam dunia konkret berarti terdapat keberkaitan manusia dengan situasi. Keberkaitan dengan situasi menunjukkan bahwa hidup manusia selalu dinamis, karena hidup konkret manusia selalu berubah sesuai dengan situasi, sehingga keberubahan ini menunjukkan adanya dinamika hidup manusia. Dinamika ini menunjukkan bahwa manusia hidup tidak hanya ke dalam tetapi juga ke luar. Inilah yang dikenal dengan sebutan bahwa manusia adalah eksistensial, yang pada perkembangan terakhir menjadi sebuah sistem filsafat yang dikenal dengan filsafat eksistensi atau eksistensialisme.

Sebagai barang dunia dan ada dalam dunia, maka manusia atau aku mempunyai keterjalinan dengan sesama manusia, sehingga adanya intensionalitas ini menunjukkan bahwa hidup manusia ada dan hadir dalam dunia tidak hanya sendirian, tetapi hidupnya dibagi bersama dengan yang lain atau manusia ada bersama dengan yang lain. Dengan kata lain, bahwa eksistensi manusia dapat dipahami sebagai koeksistensi, yaitu ada keterjalinan bersama. Dengan demikian, hidup manusia yang menghadap ke luar semakin menunjukkan adanya keotentikan aku secara konkret. Ini hanya bisa ditunjukkan dengan adanya keterbukaan kepada yang lain.

Dalam tulisan ini, penulis akan memaparkan mengenai implikasi teologis gagasan relasi Aku-Tuhan tentang pentingnya umat Islam untuk hidup bermakna dan otentik dengan serangkaian tindakan-tindakan yang bermakna terhadap alam, sesama maupun pada Tuhan dalam dimensi sosial. Di samping itu, tulisan ini akan menjelaskan pentingnya moralitas sebagai tindakan yang bermakna sebagai antitesis dari adanya kejahatan dan adanya alienasi masyarakat kontemporer baik terhadap dirinya, sesamanya maupun pada Tuhannya, yang dibuktikan dengan maraknya kejahatan, baik kejahatan natural maupun struktural, yang muncul di era kontemporer sebagai dampak dari teknologi dan individualistik akibat pengaruh kapitalisme global.

Teologi proses, nama lain panenteisme, sebagai bagian dari teologi kontemporer yang pergerakannya mulai menonjol pada akhir tahun 1960-an beranggapan bahwa segala sesuatu mengalami perubahan atau berproses. Teologi proses menolak transendensi, kemahakuasaan, dan kemahatahuan Tuhan. Istilah- 
istilah dipengaruhi oleh filsafat proses Whitehead, pertama adalah relasi internal dan eksternal. Relasi-relasi internal merupakan relasirelasi yang dapat mempengaruhi keberadaannya makhluk yang berhubungan dengan makhluk-makhluk. Relasi-relasi eksternal tidaklah merubah watak dasar atau esensi makhluk. Bagi panenteisme, relasi antara Tuhan dan dunia merupakan relasi internal di dalam Tuhan akan mempengaruhi watak dunia dan dunia mengubah sifat Tuhan. Teisme klasik menyatakan bahwa Tuhan merespon segala peristiwa dunia, namun segala peristiwa tidak dapat merubah esensi Tuhan, keniscayaan eksistensi atau sifat dasar Tuhan. Kedua, dipolar. Istilah ini merujuk kepada dua aspek dasar Tuhan. Hartshorne mengidentifikasi aspek-aspek tersebut sebagai abstrak dan konkret. ${ }^{1}$ Whitehead mengidentifikasi aspek-aspek Tuhan sebagai aspek primordial Tuhan dan aspek watak konsekuen. Ini berarti Tuhan memiliki sifat abadi dan sifat responsif. Whitehead memahami semua kenyataan dengan dipolar, yakni dalam setiap peristiwa; aspek fisik dan mental yang dipertentangkan dengan dualisme pikirantubuh.

Implikasi dari penyertaan Tuhan pada dunia adalah Tuhan yang hadir ke dunia dan dunia dipengaruhi Tuhan. Walaupun kehadiran Tuhan dalam dunia yang dapat dipahami sebagai bentuk panteisme, filsafat proses menghindari kekeliruan pemahaman tentang dunia menjadi Tuhan atau Tuhan ke dalam dunia dengan mempertahankan perbedaan antara Tuhan dan dunia. Perbedaan ini merupakan manifestasi kekekalan Tuhan dan kesementaraan dunia. Ini juga terlihat dalam kebebasan aktivitas di dunia. Meskipun Tuhan menyajikan kemungkinan untuk aktivitas di dunia, setiap kegiatan "memutuskan" bagaimana mereka yang mungkin akan aktual. Kebebasan setiap peristiwa, tidak adanya penetapan Ilahi, menyediakan sebuah cara untuk proses pemikiran untuk menghindari Tuhan sebagai penyebab kejahatan. Sejak Tuhan meliputi peristiwa di dunia, Tuhan akan menyertakan jahat dan baik yang terjadi di dunia ini.

${ }^{1}$ Charles Hartshorne dan William Reese, Philosophers Speak of God (ChicagoLondon: The University of Chicago Press, 1976), 210. Bandingkan dengan John W. Cooper, Panenteisme the Other God of the Philosophers: From Plato to the Present (Grand Rapids, MI: Baker Academic, 2006). 
Tuhan akan mempengaruhi sejak dunia mempengaruhi aktualitas Tuhan. Tetapi, karena Tuhan tidak menentukan respon dari masing-masing peristiwa untuk kemungkinan bahwa Tuhan hadir, baik melalui intensifikasi pengalaman dan aktualitas yang kurang dari intensitas pengalaman. Tuhan mengambil ini kurang intens, jahat, pengalaman ketuhanan sendiri, tetapi yang jahat menebus dengan cara relasi ke dalam cara-cara aktualisasi yang baik. Oleh karena itu, Tuhan menyelamatkan apa yang dapat diselamatkan dari dunia dari pada hanya termasuk dalam setiap kegiatan isolasi dari aktivitas lainnya. ${ }^{2}$

Memanfaatkan filsafat proses, David Ray Griffin menganggap bahwa pemahaman ilmiah tentang dunia bersifat penting dan juga memahami implikasi dari pengertian sains untuk teologi. Bagaimanapun, konsep panenteisme pada prinsipnya dibangun dari filsafat proses dari pada konsep ilmiah secara langsung. Griffin menerima penjelasan naturalistik dari kenyataan dan mengidentifikasikan materi sebagai satu-satunya kenyataan. ${ }^{3}$ Dia mengklaim bahwa bentuk teisme tradisional supernaturalistik menekankan bahwa Tuhan tidak akan memberikan alternatif yang cukup kepada pandangan hidup ateisme modern karena Tuhan menjadi sumber kejahatan. Griffin beragumentasi bahwa teisme tradisional membuat Tuhan sebagai sumber kejahatan karena kehendak Tuhan menetapkan prinsip-prinsip umum alam semesta. Proses panenteisme menyediakan cara untuk menghindari masalah baik tradisional teisme dan materialisme naturalisme. ${ }^{4}$ Griffin mengganti pandangan paneksperiensialisme untuk materialisme dan doktrin tentang persepsi yang didasarkan pada persepsi pancaindera atas model persepsi non-indrawi untuk menjelaskan masalah interaksi pikiran-tubuh, interaksi Tuhan-dunia. Tuhan dan segala peristiwa dalam interaksi di dunia melalui persepsi non-indrawi. Melalui interaksi ini, Tuhan dapat mempengaruhi tapi tidak menentukan dunia, dan dunia dapat mempengaruhi kekonkretan

${ }^{2}$ Cooper, Panenteisme..., 174, 180.

3David Ray Griffin, "Panenteisme: A Postmodern Revelation", in In Whom We Live and Move and Have Our Being, P. Clayton and A. Peacocke (eds.), (Grand Rapids, MI: William B. Eerdmans, 2004), 40-1.

${ }^{4}$ Ibid., 37, 42. 
Tuhan tanpa mengubah esensi Tuhan. Proses panenteisme mengakui dua aspek Ilahi, yang abstrak dan esensi yang tidak berubah (unchanging) dan situasi konkret negara yang melibatkan perubahan. Melalui konsep dipolar ini, Tuhan mempengaruhi dan dipengaruhi oleh dunia. Griffin memahami Tuhan sebagai esensi jiwa alam semesta meskipun berbeda dari dunia. Ide Tuhan sebagai jiwa dunia menekankan keintiman dan hubungan langsung tentang relasi Tuhan dengan dunia, bukan munculnya jiwa dari dunia. Keterhubungan adalah bagian dari esensi Ilahi, namun hal ini tidak berarti bahwa dunia secara spesifik diperlukan Tuhan. Dunia hadir menjadi ada dan bereksistensi dari ketiadaan secara relatif. Ketiadaan secara relatif adalah kekacauan bagi setiap individu bahwa karakterisitik spesifik setiap individu berkelanjutan dari waktu ke waktu. Prinsipprinsip mendasar kausalitas ini hadir bersama dengan sifat Tuhan sejak prinsip kausalitas ini melekat pada benda-benda termasuk sifat Tuhan. Implikasi penting dari dua prinsip-prinsip dasar kausalitas, tingkatan determinasi pribadi dan pengaruh sebab-musabab adalah bahwa Tuhan mempengaruhi tetapi tidak menentukan peristiwa dunia lainnya. Pemahaman naturalisme Griffin memungkinkan tindakan Ilahi sama pada semua peristiwa dunia. Namun tindakan Ilahi ini dapat terjadi dalam berbagai cara sehingga beberapa tindakan tidak terlepas dari ciri dan tujuan Ilahi. ${ }^{5}$

Teologi proses menantang pandangan tradisional tentang Tuhan yang selalu diajukan oleh kekristenan. Keyakinan tradisional tersebut mengakui bahwa Tuhan adalah sempurna dan tidak berubah (statis). Segala bentuk aktivitas manusia tidak dapat mempengaruhi atau mengubah Tuhan. Tuhan biasanya dianggap sebagai yang transenden dari dunia. Meskipun Jurgen Moltmann, seorang teolog Jerman, berpendapat bahwa pandangan tentang Tuhan seperti ini harus ditolak bila ditinjau dengan sorotan inkarnasi. Namun tantangan yang paling radikal datang dari teologi proses. ${ }^{6}$ Pada era modern, John Cobb Jr. secara signifikan telah mengembangkan filsafat Whitehead dalam

${ }^{5}$ Ibid., 43-5 178-200.

6Jurgen Moltmann, The Crucified God (Evanston, IL: Harper and Row, 1974), 
konteks teologi Kristen. Teologi proses juga merupakan suatu kepercayaan panenteistik yang mengakui bahwa segala sesuatu di dalam Tuhan, ketimbang panteistik dengan gagasan bahwa segala sesuatu adalah Tuhan. ${ }^{7}$

Teologi proses bersandar pada premis dasar bahwa segala sesuatu di dalam dunia ini selalu berada dalam perubahan atau berfluktuasi. Para filsuf proses seperti Whitehead berpendapat bahwa setiap entitas secara konstan berada dalam proses menjadi sesuatu. Dalam proses menjadi ini (process of becoming), entitas-entitas merespons setiap momen dengan membuat pilihan-pilihan nyata. Dalam konteks penentuan pilihan-pilihan harus diakui bahwa setiap momen eksistensi kita bersifat bipolar atau dwi kutub. Artinya bahwa setiap momen dipengaruhi oleh apa yang terjadi pada masa lalu dan apa yang potensial terjadi di masa yang akan datang. Sebagai yang telah terjadi di masa lalu, menyebutnya sebagai kutub "fisik" (dia sudah punya eksistensi fisik). Sebagai yang akan terjadi di masa depan, dia belum terealisasi tetapi eksis di dalam batas-batas kemungkinan (realm of possibility) dan menyebutkan ini sebagai kutub "mental" (kita sedang berpikir tentang masa depan). ${ }^{8}$

Di antara kutub-kutub fisik dan mental terdapat apa yang disebut "peristiwa-peristiwa aktual" (actual occasions). Hanya membutuhkan beberapa saat untuk menyatakan bahwa apa yang hadir sekarang (saya sedang menulis kata-kata ini) secara aktual adalah masa lalu di sini (saya sudah menulis kata-kata itu). Jadi suatu peristiwa aktual merupakan suatu realitas yang berlalu dengan cepat (fleeting), tetapi "momen"-nya tidak hilang melainkan lewat (passes) menjadi apa yang dikenal sebagai keabadian objektif (objective immortality). Kita telah mencatat bahwa masa lalu mempengaruhi masa depan, contoh: jika saya mematahkan kaki saya hari ini, saya tidak dapat lagi bermain sepakbola besok. Jadi ide bahwa masa lalu mempengaruhi masa depan berarti bahwa dalam beberapa cara masa lalu terseret maju

7John Cobb Jr., A Christian Natural Theology, Based on the Thought of Alfred North Whitehead (Philadelphia: Westminster Press, 1965), 135-55.

${ }^{8}$ Ibid. 
ke dalam masa depan. Kontinuasi masa lalu ke masa kini dikenal sebagai prehensi (prehension). ${ }^{\text {? }}$

Dalam filsafat proses, setiap momen dari eksistensi kita bersifat unik. Ini berarti bahwa dalam setiap momen suatu entitas dihadapkan dengan suatu masa depan potensial di mana dia bebas untuk menerima atau menolaknya. Para filsuf proses juga berpendapat bahwa masa depan potensial yang diterima atau ditolak sebagian besar berdasar pada bagaimana kontribusi mereka terhadap kebahagiaan atau kesejahteraan orang lain. Dalam teologi proses masa depan potensial ini (juga disebut "tujuan-tujuan awal" [initial aims]) diberikan oleh Tuhan. Lagipula, setiap momen yang berlalu tidak hilang, melainkan terserap ke dalam Tuhan dan ditambahkan ke dalam pengalaman Tuhan (God's experience). Jadi dalam setiap momen, Tuhan terusmenerus belajar setahap lebih tinggi tentang diri kita. Dia belajar sebagai Tuhan yang hadir dalam tiap momen eksistensi kita. ${ }^{10}$

Meskipun teisme klasik berpendapat bahwa Tuhan dalam beberapa cara berjarak atau transenden dengan dunia, namun dalam teologi proses Tuhan tidak terpisah dari proses-proses dunia (imanen). Sebagai Tuhan yang juga suatu entitas, Tuhan memiliki kutub fisik (masa lalu) dan kutub mental (masa depan potensial). Dalam kutub mental Tuhan mempertimbangkan semua skenario yang mungkin terjadi dan menghadirkannya di hadapan kita dalam masing-masing momen melalui entitasentitas yang "memikat" terhadap potensi mereka. Kunci keyakinan dalam teologi proses adalah bahwa Tuhan tidak pernah memaksa suatu entitas menuju suatu masa depan potensial. Tuhan juga dibatasi oleh kebebasan dari suatu entitas yang lain untuk menolak "kesan potensial" Tuhan. Dalam teologi proses kita dilihat sebagai rekan sekerja (co-worker) dengan Tuhan, bukan sebagai subjek-subjek Ilahi yang dibatasi hanya untuk melakukan kehendak Tuhan. ${ }^{11}$

'Willem B. Drees, God and Contemporary Science: Philip Clayton's Defense of Panenteisme (t.tp: Zygon, 1999), 515-25.

${ }^{10}$ Lewis Ford, (ed.), Two Process Philosophers: Hartshorne's Encounter with Whitehead, (Tuhanassee, FL: American Academy of Religion), 1973.

${ }^{11}$ Dorothy Emmett, "Whitehead and Alexander", Process Studies (t.tp: tp, 1992), 137-48. 
Dalam teologi proses, Tuhan juga menjadi penderita yang mengerti. Bagi para teolog proses Tuhan tidak maha kuasa (omnipotent) dan tidak tahu tentang masa depan. Tuhan hanya mengenal masa depan sebagai suatu aktualitas potensial, bukan realitas aktual. Ini berarti, Tuhan dalam beberapa hal terbatas. Tuhan tidak dapat memaksakan kehendak Ilahi kepada manusia dan mengawasi konsekuensi-konsekuensi dari setiap momen untuk melihat bagaimana masa depan berlangsung. Itu juga berarti bahwa dalam setiap tindakan membawa dunia ke dalam eksistensi Tuhan membutuhkan kesempatan. Seperti yang dicatat John Cobb, "Tuhan mengalami risiko dan bertualang dalam eksperimen kosmik, sambil menyisakan sumber kegelisahan dalam dunia." [God undergoes risk and adventure in cosmic experiment, while remaining the source of unrest in the world], jadi masa depan terbuka. Kemahatahuan (omniscience) berarti Tuhan mengetahui segala sesuatu yang telah terjadi hingga kini, tetapi tidak segala sesuatu yang akan terjadi. Kini sikap optimistik ini dalam perkembangannya dapat ditemukan masalah: karena Tuhan tidak maha kuasa maka tidak ada garansi bahwa kehendak baik akan berpuncak pada kemenangan alam semesta. Kenyataannya, kehendak baik hanya unggul sejauh kita menanggap kehendak Ilahi untuk "mengasihi" di antara seluruh entitas. Namun sebagai Tuhan yang tidak pernah memaksa, tetapi mendorong untuk mengikuti kehendak Ilahi, terdapat kemungkinan riil bahwa manusia bisa memilih untuk tidak mengikuti Tuhan itu sendiri. ${ }^{12}$

Secara jelas teologi proses menggeser sikap mempersalahkan apa yang salah dalam dunia yang menjauh dari Tuhan, dan masuk ke dalam kemanusiaan. Jika Tuhan memiliki potensi untuk ditolak, maka kejahatan adalah sautu hasil bentukan dari suatu proses bergerak menjauh dari Tuhan. Pilihan-pilihan "buruk" yang tidak terelakkan akan dibuat oleh berbagai entitas yang memiliki kebebasan untuk menolak atau menerima kesan Tuhan (keterpikatan Ilahi). Ini berarti Tuhan tidak dapat membiarkan kejahatan karena Tuhan tidak siap menghadapinya

12Philip Clayton, "God and World", in The Cambridge Companion to Postmodern Theology, Kevin J. Vanhoozer (ed.) (Cambridge: Cambridge University Press, tt.), 203-18. 
sejak awal. Tuduhan bahwa Tuhan bisa menjadi jahat atau impoten dengan membiarkan kejahatan, tidak berlaku di sini karena masalah ini berada di luar jangkauan tangan Tuhan. Terlebih, kuasa dan aktivitas Tuhan dibatasi karena kita punya "pilihan-pilihan riil" untuk dibuat. Kini sementara orang akan merasa tidak senang dengan pandangan tentang Tuhan seperti ini. Karena pandangan tersebut tidak memberikan kepastian bahwa dalam beberapa hal di masa depan semua akan beres di alam semesta. Itu juga mencuatkan beberapa hal untuk dipertanyakan mengenai keyakinan para teolog proses tentang hakikat Tuhan. ${ }^{13}$

Teologi proses mempunyai beberapa unsur atraktif untuk menjelaskan masalah tersebut. Misalnya, keyakinan bahwa hubungan antara Tuhan dan kemanusiaan adalah kooperasi mutual, membimbing pada hasil positif agama dalam masyarakat sejauh sebagai orang percaya yang mengikuti contoh Ilahi. Teologi proses mendorong orang percaya untuk mendengarkan dan memahami ketimbang melawan orang lain dengan "kebenaran" versi mereka, melalui kontribusi signifikan yang jauh dalam wilayah teodisi. Namun pada simpulan kita juga mencatat kontribusi penting dalam debat antara agama dan sains. Kosmologi "dentuman besar" (big bang) secara jelas memperkuat ajaran utama dalam filsafat proses bahwa dunia selalu berada dalam dinamika naik-turun (fluktuasi). Alam semesta kita bukanlah wilayah yang statis. "Hukum alam" yang telah kita observasi di masa lampau kini dipersoalkan dalam sorotan berbagai penemuan baru saintifik. Pandangan kita tentang alam semesta sebagai subjek wilayah mekanistik untuk "hukum-hukum yang pasti" (fixed laws) juga telah direvisi dalam sorotan teori kuantum.

Ada pemahaman baru tentang dunia ini, bahwa teologi proses telah memfasilitasi hubungan baru antara agama dan sains. Yakni, jika alam semesta pada hakikatnya adalah "terbuka", maka Tuhan dapat "bertindak" dalam dunia. Lebih lanjut, jika, sebagaimana postulat teolog proses, Tuhan berkarya dalam dan dengan dunia dan prosesnya, ketimbang menentang dan mengeluarkannya, maka Tuhan berkarya dalam suatu konteks

${ }^{13}$ Ibid. 
"hukum alam". Jadi menurut para teolog proses, Tuhan tidak melanggar "hukum-hukum alam", sebagaimana Tuhan tidak akan mengganggu hakikat kita. Ini berarti bahwa Tuhan dapat bertindak dalam dunia dengan cara tersendiri ketika individu secara partikular terbuka untuk kehendak Ilahi. Jika memang demikian halnya maka muncul pertanyaan apakah Tuhan telah melakukannya di masa lampau, atau akan melakukannya di masa depan. Terbuka juga pertanyaan apakah Tuhan telah menunjukkan mukjizat di masa lalu atau dapat melakukannya di masa depan? ${ }^{14}$

Ketika kita menggunakan kata "statis" di sini tidak berarti Tuhan tidak aktif melainkan lebih berarti Tuhan tidak berada dalam proses perkembangan atau perubahan, dari Tuhan yang sekarang menjadi sesuatu yang lebih baik yaitu Tuhan tidak belajar dan meningkat dalam pengetahuan yang lantas membiarkan Tuhan untuk membuat keputusan-keputusan yang lebih baik sebagai contoh, Moltmann berpendapat bahwa pandangan "statis" tentang Tuhan di mana kekristenan yang diwariskan dari Yunani mesti direvisi dalam sorotan inkarnasi seperti ketika Yesus mengalami bagaimana menjadi manusia, dan secara khusus bagaimana mengalami kematian, sesuatu berubah dalam Tuhan. Ketika Tuhan menjadi manusia, Tuhan mengalami hal-hal yang Tuhan tidak pernah alami sebelumnya. Moltmann berpendapat bahwa hal ini mengandung efek dramatis pada siapa Tuhan sebagai Tuhan yang telah belajar bagaimana menjadi manusia seutuhnya. ${ }^{15}$

\section{Imanensi dan Transendensi: Relasi Aku-Tuhan}

Tuhan yang imanen adalah Tuhan yang hadir dalam diri setiap manusia, setiap makhluk hidup, dan dalam alam semesta. Gambaran tentang Tuhan ini membuat alam semesta menjadi tempat memantulkan kemahakuasaan dan penyingkapan kekayaan rahmat Tuhan dan tubuh menjadi tempat ibadah yang murni untuk menemui Sang Pencipta. Setiap manusia adalah unik dan dalam kunikan tersebut Tuhan hadir. Kekhasan dan

\footnotetext{
${ }^{14}$ Carl Gillett, "Physicalism and Panenteisme: Good News and Bad News", Faith and Philosophy, 2003, 20.

${ }^{15}$ Moltmann, The Coming..., 137.
} 
keunikan tersebut adalah kekayaan serentak sebuah kekurangan bagi diri sendiri. Karena itu setiap usaha mencari dan menjumpai Tuhan adalah usaha untuk mewujudkan diri secara sempurna. Karena keberadaan Tuhan pada dasarnya adalah unik sesuai dengan kodrat manusia, maka perwujudan diri manusia itu tidak lain adalah menemukan kesadaran akan keunikan dan kekhasan diri, yakni bakat-bakat atau potensi yang terkandung dibalik raganya.

Pada sisi ini manusia menjadi "sama seperti" Tuhan, melaksanakan karya penciptaan, mengubah dunia sesuai kehendak dan kebutuhannya, juga membawa dunia kepada tujuannya, yakni bersatu dengan Tuhan adalah awal dan akhir kehidupan. Pada sisi imanensi Tuhan dapat dipertanggungjawabkan. Tuhan yang imanen itu bekerja pada tataran tujuan, dengan memberikan horizon awal bagi manusia dan dunia untuk berkembang dan semakin mengarah kepadanya. Artinya Tuhan hadir secara intensional, sebagai tujuan hadir dalam gerak mengarah pada Tuhan. Dalam keterarahan itu Tuhan menghendaki manusia dan dunia menjadi "seperti Dia" bersatu dengan-Nya. Tuhan dalam posisi ini adalah Tuhan yang terlibat dalam prinsip dan cara kerja manusia dan dunia. Di sini Tuhan hadir "secara fisik" sejauh Ia memberikan eksistensi seluruh ciptaan-Nya. Dia memadukan penciptaan-Nya itu dalam hubungan yang amat erat, sehingga dapat dikatakan bahwa Dia dekat dengan kita, dalam Dia kita hidup, bergerak dan ada. Sebagaimana yang sudah dijelaskan dalam Qs. al-Hadīd (57): 3, Allah berfirman:

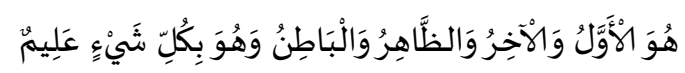

Artinya: "Dialah Yang Awal dan Yang Akhir, Yang Zahir dan Yang Batin dan Dia Maha Mengetahui segala sesuatu".

Berdasarkan ayat di atas babwa Tuban adalab awal dan akbir segala sesuatu. Sebagai awal, segala sesuatu datang dari Tuhan, segala sesuatu diciptakan oleh Tuhan. Yang Awal ialah yang telah ada sebelum segala sesuatu ada. Tuhan juga adalah akhir karena segala sesuatu bergerak mengarah kepada Tuhan. Dengan kata lain, Yang Akhir ialah yang tetap ada setelah segala sesuatu musnah. Tuhan adalah tujuan segala sesuatu, artinya 
kesempurnaan segala sesuatu yang hanya terwujud dalam kesatuannya dengan Tuhan. Sebagai makhluk yang terbatas, manusia tidak dapat menemukan sesuatu dalam dunia. Alam pun harus mengarah menembus batas eksistensinya untuk mencapai kesempurnaan. Singkatnya manusia dan dunia membutuhkan Tuhan sebagai tujuan akhir dari segala usaha dan perjuangannya menemukan makna kehidupan yang sempurna. Dalam pandangan ini transendensi Tuhan dapat dijelaskan. Keterarahan manusia dan dunia terhadap Tuhan membuktikan bahwa Tuhan adalah yang transenden. Artinya Tuhan melampui dunia, berbeda sama sekali dari dunia, eksistensi-Nya pun sama sekali tidak tergantung dari apakah dunia ada atau tidak. Dia memiliki kepenuhan kekayaan, kemegahan, tak terbatas, tak terhingga, sempurna, penuh, dan utuh. Transenden adalah apa yang seluruhnya berbeda dari "ada-ada" yang lain. Perbedaannya terletak pada "adanya" sendiri dan pada apa yang ada dalam diriNya. Kekhasan ini yang melanjutkan usaha tersebut sampai pada kesempurnaan yang infinitum. Disinilah maksud dari yang Zähir ialah yang nyata adanya karena banyak buktinya, dan yang Bätin ialah yang tidak dapat digambarkan hikmat zat-Nya oleh akal.

Pembahasan tentang Tuhan merupakan fenomena baru di kalangan masyarakat modern yang rasional. Fenomena baru ini, bagi masyarakat modern yang serba mekanis merupakan antitesis dari pengaruh positivisme ${ }^{16}$ yang menolak metafisika, etika bahkan agama, karena ketiga hal tersebut kebenarannya tidak

\footnotetext{
${ }^{16}$ Suatu kebenaran dapat dianggap benar apabila sesuai dengan hukum positif yang sesuai dengan fakta-fakta atomik, sehingga dapat dianggap ilmiah. Sedangkan metafisika, etika maupun agama tidak dapat dibuktikan unsur-unsur atomiknya, sehingga tidak dapat dikatakan sebagai kebenaran ilmiah. Gagasan ini dirumuskan oleh filsuf Perancis bernama Auguste Comte. Salah satu teori terkenal dari Comte adalah teori evolusi masyarakatnya. Comte melihat bahwa masyarakat dunia bergerak pada tiga tingkatan intelektualitas. Tingkat pertama adalah tahapan teologis di mana sistem pemikiran masyarakat tahap pertama ini dicirikan melalui kepercayaan terhadap kekuatan supranatural. Tingkat kedua adalah tahapan metafisis di mana masyarakat pada tahap ini dicirikan melalui kepercayaan mereka terhadap kekuatan "abstrak", dibandingkan ide Tuhan yang personal, dalam menerangkan keberadaan dunia. Tingkat ketiga adalah tahapan positivistis di mana masyarakat berkembang melalui kepercayaan mereka terhadap ilmu pengetahuan (ala positivisme tentunya). Lihat, George Ritzer, Modern sociological Theory (Singapore: the McGraw-Hill Companies Inc., 1996), 14.
} 
dapat diverifikasi. ${ }^{17}$ Hanya saja, pembahasan tentang Tuhan bagi masyarakat modern berbeda dengan era patristik ${ }^{18}$ (abad pertengahan) yang cenderung teosentris. ${ }^{19}$ Era sekarang, pembahasan tentang Tuhan difokuskan pada pembahasan filosofis dengan titik tekan pada antroposentris, ${ }^{20}$ di mana manusia menjadi tolok ukur dalam hubungannya dengan eksistensi Tuhan. Pada ranah filosofis ini, manusia telah memakai pendekatan epistemologis dalam membahas Tuhan sebagai upaya pembuktian secara ilmiah, rasional, dan logis.

Apa yang disentuh dalam pengalaman religius adalah hidup dalam arti yang sesungguhnya, yakni sebagai rahasia yang

\footnotetext{
${ }^{17}$ Verifikasi merupakan kata kunci kaum positivisme dalam memandang sebuah teori yang dianggapnya sebagai yang ilmiah. Verifikasi merupakan metode pengujian sebuah teori, sebagai langkah awal dalam mencari bukti-bukti yang membenarkan untuk meneguhkan kebenarannya.

${ }^{18}$ Patristik berasal dari kata patriarchi yang berarti bapak. Dalam sejarah filsafat, era patristik merupakan era di mana Bapak-bapak Gereja (Pastur) menjadi sentral pembahasan filsafat. Era ini juga diidentikkan dengan Scholastik di mana Bapakbapak Pastur di Gereja menjadi pengajarnya. Istilah ini mempunyai makna aliran (mazhab) sebagai corak yang khas dari filsafat abad pertengahan. Scholastik dapat dirumuskan sebagai sebuah sistem filsafat yang mempunyai corak semata-mata bersifat agama. Di samping itu, juga dianggap sebagai filsafat yang mengabdi pada bidang teologi (ancila teologi) atau filsafat berpadu dengan agama yang berusaha secara rasional memecahkan persoalan-persoalan dengan wahyu. Lihat, A. Epping OFM. Et.all., Filsafat ENSIE (Bandung: Jemmars, 1983), 126-40. Bandingkan dengan Frank Thilly yang beranggapan bahwa Scholastisism ini menunjuk arti diberlakukannya pengajaran sistem sekolah yang didirikan oleh Charles, seorang generasi baru dari kelahiran kembali filsafat Patristik. Zaman ini merupakan abad pertengahan yang dicirikan dengan teosentris. Pada era ini, keimanan menjadi landasan utama dalam pembahasan filsafat. Filsafat dipergunakan untuk memperkuat iman Kristen. Frank Thilly, A History of Philosophy (New York: Holt, Rinehart and Winston, 1957), 193.

${ }^{19}$ Teosentris merupakan ciri utama abad pertengahan yang berarti teologi menjadi dasar dari segala-galanya untuk membuktikan keimanan atau keimanan mencari pendasaran filsafat. Dengan kata lain, pembahasan tentang Tuhan menjadi sentral utama abad ini. Lihat, Frank Thilly, A History,..., 193. Pada era ini filsafat dan pengetahuan menjadi ancila teologi atau hamba teologi. Filsafat dan pengetahuan dipergunakan para teolog untuk membuktikan iman atau Iman dipahami secara rasional filosofis, dalam istilah Anselmus, Intellectum Fidei. Suhermanto Ja'far, Konsep Metafisika Moh. Iqbal (Jakarta: Tesis PPS Filsafat UI, 2003), 54-7.

${ }^{20}$ Antroposentris merupakan ciri utama filsafat modern yang berarti manusia menjadi sentral utama pembahasan. Manusia menjadi titik tolak dalam memandang segalanya termasuk Tuhan. Manusia menjadi subyek sekaligus obyek pembahasan filsafat. Bertrand Russell, History of Western Philosophy (London: George Allen \& Unwin, 1974), 157.
} 
mempunyai akarnya dalam keseluruhan realitas. Maka pengalaman ini ialah mengenai apa yang tidak dapat dikatakan, yang merupakan dasar dari segalanya dan sekaligus melebihi segala-galanya. ${ }^{21}$ Pengalaman di atas menjadi obyek metafisik. Disebut demikian, karena pengalaman itu hadir sebagai fakta. Maksudnya saya melihat sesuatu ada, tetapi sama sekali tidak mempengaruhi adanya di hadapan saya. Dalam arti tertentu, saya sebagai subyek bersifat pasif. ${ }^{22}$

Relasi Tuhan dengan manusia maupun alam merupakan fenomena baru masyarakat modern dalam memahami Tuhan, sehingga pendekatan epistemologis menjadi sebuah keharusan. Tuhan dipahami dalam perspektif antroposentris dengan titik tekan pada relasi antara Tuhan dengan manusia dan alam. Relasi antara Tuhan dengan manusia menimbulkan pemikiranpemikiran yang secara filosofis cenderung imanen pada satu sisi dan transenden pada sisi yang lain, bahkan menimbulkan pemikiran yang menganggap bahwa Tuhan itu imanen sekaligus transenden.

Imanensi maupun transendensi merupakan paradigma ontologis-metafisis di kalangan filsuf maupun teolog dalam membahas relasi antara manusia dengan Tuhan. Di sinilah terdapat benang merah relasi manusia dan Tuhan dengan pendekatan fenomenologis yang dikenal dengan istilah intentionalitas. $^{23}$ Istilah ini merujuk bahwa manusia mempunyai keterarahan dengan yang lain, termasuk Tuhan. Keterarahan

${ }^{21}$ Theo Huijbers, Manusia mencari Allah (Jogjakarta: Kanisius, 1982), 68.

${ }^{22}$ Lorenz Bagus, Metafisike (Jakarta: Gramedia, 1991), 22.

${ }^{23}$ Intensionalitas merupakan istilah yang dipopulerkan Husserls sebagai kata kunci dalam fenomenologi. Istilah Intensionalitas berarti, mengarah, mempunyai arah atau tujuan, menuju ke. Konsep ini pertama-tama digunakan oleh Brentano untuk membedakan antara fenomena fisik dengan fenomena psikis. Benda-benda fisik tidak terdapat di dalamnya apa yang disebut intensionalitas (bertujuan ke atau mengarah ke). Intensionalitas menunjuk makna aktivitas, yaitu "mengarah ke obyek atau menuju ke obyek". Untuk Lebih jelasnya baca, Khozin Affandi, Fenomenologi: Pemahaman awal pikiran-pikiran Edmund Husserl (Surabaya: eLKAF, 2007), 37-40. Adanya relasi Subyek dan Obyek yang berkesadaran ini akhirnya melahirkan istilah Cogita cogitata pada fenomenologi Husserl. Ini dibuktikan dengan konsep intensionalitas yang dikandung oleh Subyek dengan kesadarannya, sehingga dapat mengarah langsung pada Obyek yang juga mempunyai kesadaran. Lihat, Theodore de Boer, The Development of Husserl's Thought (London: Trans Mortinus Nijhhoff, 1978), 102. 
manusia kepada Tuhan merupakan suatu keniscayaan. Keterarahan ini semakin jelas dalam pandangan Martin Buber sebagai wujud keterarahan aku dengan Tuhan.

Martin Buber menganalogikan keterarahan manusia pada Tuhan dengan keterarahan pada benda, yang disebut dengan istilah relasi Aku-itu dan Aku-Engkau. Menurut Martin Buber relasi Aku-itu dan Aku-engkau merupakan cara untuk mewujudkan kesadaran Aku. Artinya, bahwa kesadaran $A k u$ bukan tunggal yang hanya ditentukan oleh subyek dirinya, tetapi ditentukan oleh subyek lain (aku lain) yang dinamakan Engkau. Jadi Engkau merupakan suatu dimensi baru meng-ada-kan Aku dalam hubungannya dengan aku lain. Karenanya, hanya dengan pertemuan personal Aku-Engkau, aku mengalami kesadaran dan kehadiran yang nyata. Kehadiran Aku dan Engkau merupakan sisi dari proses menjadi Ada. Berangkat dari hal ini, Buber memandang manusia, yaitu Aku selalu dalam relasi dialogis dengan benda-benda (I-it) maupun dengan sesama dan Tuhan (IThou). Relasi dialogis ini merupakan suatu keharusan dalam perjumpaan dengan Engkau. Perjumpaan ini menyebabkan $A k u$ menjadi Ada karena Engkau, sebagaimana ucapannya, "Aku membutubkan Engkau untuk menjadi Ada, Aku Ada, karena Aku berkata Engkau. ${ }^{24}$

Pada akhirnya kesadaran yang terdapat pada Aku sebagai inti kepribadian manusia merupakan aktivitas Jiwa. Sehingga kesadaran atau suara hati merupakan aspek etis yang menempatkan roh sebagai bentuk yang paling tinggi dari semua itu, dan dianggap sebagai jendela jiwa yang terarah pada Allah. ${ }^{25}$ Karena itu, di balik kesadaran manusia terdapat sesuatu yang turut beraktivitas dalam kehidupan, sehingga membawa manusia pada yang Mutlak, yaitu Roh. Keterarahan pada yang Mutlak itu merupakan sesuatu yang Given bagi manusia, karena Allah merupakan ide innate manusia, sebagaimana teori Plato dan Descartes. $^{26}$ 5.

${ }^{24}$ Martin Buber, I and Thou, trans. W. Kauffman Edinburgh (t.tp: tp, 1970,) 54-

${ }^{25}$ C.A. Van Peursen, Orientasi di Alam Filsafat, ter. Dick Hartoko (Jakarta: Gramedia, 1988), 239-40.

${ }^{26}$ There is in man an innate knowledge of God and consciousness of divinity (sensus divinitatis) which can no more be wanting in him, that an rational intellect; and which he can no 
Relasi keduanya yang melahirkan konsep imanensi dan transendensi ini dalam perkembangan berikutnya menimbulkan faham-faham ketuhanan yang menjadi perdebatan di antara paham-paham tersebut. Tuhan dianggap sebagai imanen sekaligus transenden bagi penganut teisme. Tuhan dianggap sebagai transenden terhadap alam dan manusia bagi kaum deisme. Tuhan dianggap sebagai yang imanen bagi kaum panteisme. Di samping itu, ada juga yang pesimis bahwa akal manusia bisa menjangkau Tuhan sebagaimana kaum agnostisisme.

Relasi Tuhan dengan manusia dan alam tidak hanya menjadi perdebatan kaum teis, tetapi juga menjadi perdebatan kaum ateis dan antiteis. Ateisme merupakan paham yang menolak kepercayaan adanya Tuhan. Ateisme merupakan antitesis dari konsep teisme. Sedangkan antiteisme merupakan paham yang melawan terhadap paham yang percaya pada Tuhan. Relasi Tuhan dengan manusia dan alam ini menjadi perdebatan para teolog dan filosof sepanjang sejarah manusia.

Relasi Tuhan dengan manusia dan alam yang dikonsepsikan para teolog yang cenderung spiritualis-monistik beranggapan bahwa peleburan dalam relasi tersebut akan melenyapkan eksistensi manusia dan alam sebagaimana menjadi pegangan kaum panteisme. Sementara itu, di kalangan masyarakat modern yang rasional melalui pendekatan epistemologis beranggapan bahwa peleburan dalam relasi tersebut tidaklah menghilangkan eksistensi manusia dan alam tetapi justeru semakin mengeksiskan manusia. Ini adalah anggapan kaum panenteisme.

Persepsi panenteisme mengenai Tuhan ini menjadi fenomena baru masyarakat modern, karena paham ini tidak menafikkan kemampuan dan kebebasan manusia. Fenomena ini berangkat dari pemahaman epistemologis tentang eksistensi Tuhan relevansinya dengan pengetahuan ilmiah, sehingga paham ini masih menghargai pengetahuan ilmiah dalam memahami Tuhan. Pengetahuan ilmiah menjadi perangkat metodologis dalam memahami eksistensi Tuhan. Tuhan tidak hanya dipandang dalam perspektif teologis saja. Eksistensi Tuhan

more get rid or than he can get rid of himself. Lihat, Sheed's, Dogmatic Theology (USA: Thomas Nelson Publisher, 1980), 199. 
menjadi perdebatan yang panjang antara panteisme dengan panenteisme mengenai relasi yang disertai dengan peleburan manusia dengan Tuhan.

Tuhan menurut Iqbal mencipta secara tak terbatas dan kreatif terus menerus di mana posisi manusia bukanlah boneka pasif bagi kehendak Tuhan melainkan co-creator yang aktif berpartisipasi dalam penciptaan kreatif Tuhan. ${ }^{27}$ Proses penciptaan oleh Tuhan menurut Iqbal bukan seperti proses penciptaan sepatu yang kreativitasnya berada pada level paling rendah. Proses penciptaan oleh Tuhan dapat diasosiasikan dengan creative genius seorang komposer atau penyair. Manusia sebagai co-creator pilihan Tuhan berbagi creative genius Tuhan untuk direalisasikan dalam dunia atau sederhananya: manusia diberkahi Tuhan kebebasan untuk dapat berpartisipasi aktif dalam proses kreatif penciptaan-Nya. Berangkat dari pemahaman Iqbal ini, maka Iqbal merupakan pengikut dari panenteisme atau teologi proses. Karena itu, relevan sekali Hartshorne dan William Reese memasukkan Iqbal sebagai panenteis Muslim. ${ }^{28}$

Berdasarkan pada pemahaman imanensi dan transendensi Tuhan, maka imanensi dan transendensi Tuhan dalam dunia selalu berjalan bersamaan. Tuhan bersifat baik transenden maupun imanen terhadap dunia. Mengapa yang Ilahi itu imanen dan bukan tergantung hanya transenden terhadap dunia? Karena dunia sebagai realitas tidak mutlak seluruhnya tergantung dari, atau berdasarkan pada Yang Mutlak. Jadi unsur apapun dalam dunia hanya bisa ada karena ada yang Ilahi yang menunjangnya.

Kesatuan antara keduanya, yang imanen dan transenden. Tuhan itu di manapun tidak dapat ditemukan sebagai salah satu objek atau unsur, akan tetapi di manapun ia dapat ditemukan sebagai dasarnya. Di dalam dunia kita tidak dapat mencari atau menemukan Tuhan sebagai satu objek yang lain. Di manapun

${ }^{27}$ The concept of the concrete world embodied in the Koran is essentially one of a created reality in which the actual and the ideal merge and intertwine and which exhibits a distinct rational pattern. But it is not, for that reason, a 'block universe' or finished product which God has completed, but rather a universe that continually realizes itself across the vast expanses of space and time. Man, as the most dynamic force in this universe, is the principal agent, or coworker with God, in the process of realizing the infinite potentialities of reality. Lihat, Majid Fakhry, $A$ History of Islamic Philosophy (New York: Columbia University Press, 1983), 351.

${ }^{28}$ Hartshorne dan Reese, Philosophers..., 295. 
kita mencarinya kita tidak akan menemukannya. Tetapi apabila kita mencari syarat-syarat kemungkinan kita berada dan beraktivitas dalam dunia, kita dapat menyadari atau merasakan kehadiran Tuhan di mana-mana. Kita dapat menemukan Tuhan dalam segala-galanya.

Namun demikian bukan berarti saya menghilangkan sisi transenden dari Tuhan. Sebab menurut saya, sekalipun Tuhan ada dalam segala sesuatu dan segala sesuatu ada dalam Tuhan, itu tidak berarti bahwa segala sesuatu itu identik, atau sama dengan Tuhan. Yang saya yakini tentang adanya kesatuan antara Tuhan dan makhluk, tentang Tuhan yang diyakininya hadir di mana-mana, dalam diri manusia, kehidupan dengan segala dimensinya, dan alam semesta dalam hakikat cinta, tetap ada 'jurang', ada jarak antara keduanya. Tuhan yang begitu dekat dan menyatu dengan makhluk ciptaan-Nya, bagi saya hanya merupakan sebuah bentuk kesimpulan berdasarkan pengamatan analogis, yakni berdasarkan kesamaan unsur-unsur seolah-olah menyerupai dan bukan sama persis, karena dalam unsur-unsur tersebut termuat perbandingan yang lengkap satu sifat terhadap sifat yang lain. ${ }^{29}$

Dengan demikian, menurut saya paham Tuhan bukanlah seperti yang ada dalam bentuk panteisme. Sebab dalam panteisme Tuhan bersemayam dalam segala-galanya. Alam raya dipenuhi dengan Yang Ilahi dengan semua kekuatan-Nya. Panteisme menekankan kepekaan yang tinggi terhadap kehadiran Yang Ilahi dalam dunia. Ia sangat menegaskan imanensi Yang Ilahi. Demikian juga saya tidak menekankan paham Tuhan seperti dalam deisme, yang melulu menekankan transendensi Ilahi. Tuhan yang terpisah dari dunia, yang sedemikian jauh dari manusia dan alam semesta, sehingga Ia tidak mencampuri peristiwa-peristiwa dunia ini. Tuhan yang menentukan hukumhukum alam, yang memadai untuk mengatur peredaran dunia sesuai dengan apa yang ditentukan semenjak dunia ini diciptakan-Nya. ${ }^{30}$

${ }^{29}$ William L. Rowe, "Does panenteisme reduce to panteisme? a response to Craig”, International Journal for Philosopby of Religion, 2007, 61.

${ }^{30}$ Ibid., 65-7. 
Dengan demikian, penulis meyakini bahwa Tuhan sungguhsungguh lebih bersifat panenteistik. Panenteisme lebih menegaskan segala sesuatu ada dalam Tuhan. Tuhan begitu meresapi jagat raya sehingga segala sesuatu berada dalam Tuhan. Berdasarkan imanensi dan transendensi Tuhan ini, semakin menampakkan ada kita bahwa secara realitas Tuhan yang menurut hakikatnya melampani dunia, juga berada di dalam dunia, Ia imanen di dalam dunia sebagai inti yang menopang segala sesuatu. Artinya, Tuhan dipandang sebagai kedalaman eksistensinya. Kedalaman eksistensi di sini, yakni memahami Tuhan dengan berpijak pada kehidupan itu sendiri. Sebuah perenungan yang mendalam atas dimensi kehidupan manusia. Dengan demikian bagi Tuhan adalah imanen juga transenden. Tuhan sekaligus di dalam dan di atas. Mengenai imanensi dapat dikatakan bahwa Tuhan adalah dasar kreatif permanen dari dunia dan transendensi Tuhan menunjuk pada 'jurang' yang memisahkan yang takterbatas dan terbatas.

Ringkasnya bahwa, dalam panenteisme baik transendensi dan imanmensi Tuhan ditampung untuk menunjukkan ciri personal Tuhan. Dasar dari panenteisme adalah distingsi nyata antara Tuhan dan alam semesta, dan relasi nyata timbal balik di antara keduanya. Di satu pihak, entitas Tuhan berbeda dengan dunia karena Tuhan mencakup totalitas kemungkinan termasuk kemungkinan yang tidak terbatas sesuai dengan struktur kosmis yang de facto ada. Sedang di pihak lain Tuhan juga unik karena Tuhan menyerap ke dalam diri-Nya seluruh alam semesta. Dalam pandangan panenteistik personalitas Tuhan ditemukan.

Dari sisi pemahaman teologis, panenteisme berbeda dengan deisme yang hanya menganggap bahwa Tuhan terpisah dengan alam. Di sini transendensi Tuhan sangat dominan. Tuhan juga berbeda dari panteisme dalam mengidentifikasi relasi Tuhan dengan alam bahwa semuanya adalah satu yaitu wujud Tuhan. Dalam pemahaman ini Tuhan memang cenderung dipahami sebagai alam sebagaimana sering dipahami panteisme.

Menurut Hartshorne, panenteisme dapat dipahami melalui analogi: sama seperti satu organisme ada, baik sebagai kumpulan semiautonomous, setiap sel-sel individu dan mandiri sebagai individu yang lebih menonjol daripada kumpulan sel. Tuhan 
dapat dilihat sebagai kumpulan semua unsur bagian dari realitas dan sebagai "sesuatu yang lebih" dari alam semesta itu sendiri. Walaupun kita, bersama dengan sisa dari keberadaan, namun dapat dipikirkan sebagai bagian dari "tubuh" Tuhan. Kesadaran atau pikiran Tuhan yang lebih luas melampaui tubuh dan menyebabkan Tuhan menjadi lebih daripada sekedar kumpulan bagian. ${ }^{31}$

\section{Implikasi Teologi}

Adanya sifat yang taktersentuhkan dari aku ini menunjukkan bahwa manusia atau aku benar-benar penub misteri. Kemisterian ini ditandai dengan hidupnya yang tidak bisa ditembus orang lain secara total, tetapi pada hal lain manusia atau sang aku mempunyai ciri yang takterduga dan takterkatakan. Manusia yang dicirikan sebagai aku dengan segala keunikan, keotentikan melalui kesadaran dan keterbukaan bagi dirinya yang tidak dapat disentuh, justeru menjadikan manusia sebagai orang asing bagi dirinya. Karena itulah, manusia berbicara tentang aku yang makin berjauhan, sehingga inti pribadi manusia, yaitu aku tetap tinggal terselubung dan penuh tanda tanya. Dengan penuh teka-teki untuk dirinya sendiri, manusia selamanya masih tetap dalam proses menjadi. Itulah sesuatu dalam aku yang tidak dapat disentuh dan diselami. Karena manusia selalu dalam proses menjadi manusia, maka manusia merupakan pengarang hidupnya dan pencipta sejarah hidupnya, sehingga manusia akan selalu berdialog dengan ruang dan waktu hidupnya. Inilah ciri historisitas manusia sebagai ciri yang paling hakiki dari aku.

Dengan adanya dimensi historisitas ini, maka tiap-tiap aku merupakan makhluk yang menyejarah dan membuat sejarahnya sendiri. Dimensi historisitas ini menjadikan manusia mempunyai kebebasan dalam hidupnya dan bertanggungjawab secara penuh terhadap dirinya. Kebebasan aku tercermin dalam perilaku, aktivitas, dan perbuatannya yang ditentukan oleh manusia sendiri atau tindakan otonom manusia ditentukan oleh kesadarannya. Artinya, tindakan otonom dari sang aku selalu dapat dikembalikan kepada sang aku dan tindakan tersebut telah disadari secara utuh oleh aku. Karena itu, kebebasan sang aku

\footnotetext{
${ }^{31}$ Hartshorne dan William Reese, Philosophers..., 312.
} 
merupakan konsekuensi logis harus dapat dipertanggungjawabkan kepada aku pribadinya.

Di samping hidup manusia atau aku mempunyai keterarahan kepada dunia dan sesama manusia, juga ada keterarahan lain yang tidak kalah pentingnya, yaitu keterarahan kepada Allah. Keterarahan hidup manusia yang bersifat terbuka ini semakin menampakkan eksistensi kemanusiaan Aku, baik terhadap dunia, sesama maupun kepada Allah. Dengan demikian menunjukkan bahwa hidup manusia merupakan suatu kesatuan, di mana tidak ada keterarahan yang terpisah satu sama lain. Keterarahan hidup manusia kepada Allah juga akan melibatkan secara dialogisdialektis keterarahan kepada dunia maupun sesama, begitu sebaliknya, sehingga semua bidang kehidupan saling meneguhkan satu sama lain.

Keterarahan manusia pada yang lain merupakan wujud eksistensi aku yang ada bersama yang lain. Keterarahan manusia aku kepada sesama (aku lain) semakin nampak peristiwa rasa malu dari Sartre dan cinta kasib dari Gabriel Marcel. Kedua peristiwa tersebut merupakan bukti bahwa manusia hidup dibagi bersama dengan yang lain. Keterarahan aku akan terasa nyata dan langsung akan kehadiran engkau melalui kesadaran cinta. Bagi Marcel, kesadaran cinta akan membentuk suatu communion (kebersamaan) yang berlangsung dalam persahabatan yang perennis (abadi) antara Aku yang ada bersama yang lain. ${ }^{32}$

Sebagai bagian dari perbuatan Tuhan, kebebasan tidaklah mutlak sebagaimana pandangan kaum Qodariyah, hanya saja seperti kebebasan sel tubuh yang juga tidak mutlak. Pada saat yang sama, pemikiran dan tindakan manusia tidak tergantung atau dikontrol oleh Tuhan lebih dari apapun sebagaimana pandangan kaum Jabariyah yang dapat mengontrol secara sadar dan tindakan langsung dari masing-masing sel. Mungkin lebih dari sekedar sel-sel, namun sangat tergantung pada tindakan selsel yang independen dari pikiran agar tumbuh dan bahkan ada di tempat pertama.

Walaupun lebih dari seratus tahun perkembangannya, panenteisme terus berkembang dan berubah. Sebagian besar

${ }^{32}$ Lihat: PA. Van der Weij, Filosoffilosof Besar tentang Manusia (Jakarta: Gramedia, 1985), 180-82. 
pertumbuhan ini telah terjadi sebagai akibat dari kemajuan ilmu pengetahuan. Dorongan lain untuk mengubahnya adalah dibangkitkannya kritik alternatif utama pemahaman panenteistik tentang relasi Tuhan-dunia. Sebagai upaya untuk menemukan jalan tengah antara berpikir tentang Tuhan sebagai eksternal kepada dunia dan berpikir sebagai Tuhan identik dengan dunia. Panenteisme diperlawankan oleh orang-orang yang menemukan berkurangnya penekanan pada transendensi Tuhan, sehingga banyak orang yang menganggap pemahaman ini tidak memadai. Banyak orang berpaling pada pemahaman panteisme yang dianggapnya lebih memadai daripada perbedaan antara Tuhan dan dunia. Akhirnya, dari berbagai versi panteisme menyebabkan adanya kritik internal secara aktif oleh berbagai versi. ${ }^{33}$

Salah satu dari dua tipe panenteisme yang disebutkan di atas, dianggap sebagai resolusi kesulitan filosofis yang sangat erat kaitannya dengan doktrin panteisme. Misalnya, beberapa klaim yang menyatakan bahwa konsep panteisme secara penuh terhadap imanensi Tuhan dalam arti kuasa yang diatributkan kepada Tuhan sebagai sesuatu yang lebih dari pada transendennya Tuhan. Dalam panenteisme, walaupun Allah, tentu saja, selalu hadir secara imanen terhadap dunia, ia juga memiliki semua transendensinya dalam pandangan para teis tradisional tentang konsep Tuhan. Dengan demikian, bukan hanya panenteisme yang memberikan isu-isu filosofis, tetapi ia juga menjadi jembatan kesenjangan antara teisme dan panteisme. Lebih lanjut, panenteis merasa bahwa pandangan filosofis mengafirmasikan tentang kebebasan manusia dengan cara yang bukan teisme atau panteisme. Teisme menyangkal panteistik ekuasi dunia dengan Tuhan dan panteisme dapat dilihat sebagai penolakan keberadaan individu yang memilih bagian dari Tuhan, panenteis percaya bahwa mereka memberikan pandangan yang meliputi semuanya adalah kesempurnaan Tuhan secara penuh. Sementara pada saat yang sama juga menegaskan realitas individu dan kemampuan mereka untuk memilih secara bebas di dalam Tuhan.

${ }^{33}$ William L. Rowe, Does..., 65-7. 
Gagasan panenteistik tentang kebebasan adalah cara yang unik dalam membahas masalah kejahatan. Sementara teisme cenderung atribut jahat hanya pada dunia dan panteisme cenderung mengidentifikasi kejahatan di dunia sebagai kejahatan Tuhan, panenteisme mengambil posisi jalan tengah, sedangkan yang mengatakan bahwa kejahatan yang terjadi melalui kebebasan di dunia ini tidak berpengaruh pada esensi Tuhan, Tuhan masih dapat dirasakan melalui pengalaman dalam. ${ }^{34}$ Ini posisi jalan tengah mungkin merupakan kasus panenteisme dari jenis pertama, namun karena ini sebagian panteistik, condong ke arah gagasan yang jahat di dunia dengan Allah.

Meskipun filosofi panenteisme jembatan dari kesenjangan paradigma antara teisme dan panteisme, yang banyak dipahamioleh sejumlah besar kelompok agama dan teologi, juga bukan dari sekte kecil atau pandangan filosofi pribadi. Elemen panenteisme muncul di hampir setiap sistem keagamaan yang diberikan setiap kali digambarkan, sebagai baik seluruhnya, tetapi juga sangat kuasa terhadap eksistensi dunia. Transendensi dan imanensi Tuhan terlihat hampir setiap agama lebih tegas disebut sebagai Tuhan "dua sisi" oleh teolog reformed Belanda Hendrikus Berkhof35 dan "dipolar teisme" dalam proses teologi. ${ }^{36}$ Dengan kata lain, perlu dicatat bahwa panenteisme, terutama dari jenis yang kedua mendapatkan momentum teolog kontemporer di antara agama dan filsafat, yang dapat diterima sebagai alat untuk merekonsiliasi kesulitan dengan kepercayaan mengenai sifat Tuhan.

Panenteisme dapat disebut juga teologi proses yang hadir sebagai bagian dari teologi kontemporer yang pergerakannya mulai menonjol pada akhir 1960-an yang beranggapan bahwa segala sesuatu mengalami perubahan atau berproses. Teologi proses yaitu sebuah "teologi tentang mengada". Sebagai Teologi tentang mengada, maka teologi proses atau panenteisme menuntut adanya realitas tunggal yang absolut dan terserap

${ }^{34}$ Griffin, David Ray, Panenteisme...., 46.

${ }^{35}$ Hendrikus Berkhof. Christian Faith: An Introduction to the Study of the Faith, revised ed., trans. Sierd Woudstra (Grand Rapids, MI: William B. Eerdmans Publishing Co., 1986), 114.

${ }^{36}$ John B. Cobb, Jr. and David Ray Griffin. Process Theology: An Introductory Exposition (Westminster John Knox Press, 1977), 47. 
dalam eksitensi manusia, sehingga manusia atau Aku yang berada dalam Tuhan haruslah benar-benar menutut manusia menjadi eksis, hidup otentik dan bermakna dengan menekankan pada sifat-sifat labut dalam diri manusia.

Sifat labut yang menyerap nilai-nilai ketuhanan dalam diri manusia menjadikan Aku otentik dan bermakna dengan melakukan tindakan-tindakan yang bermakna sebagai prasyarat mengatasi krisis kemanusiaan global yang menghinggapi masyarakat di era kontemporer. Hidup otentik adalah hidup dengan kehadiran keseluruhan eksistensi kita. Setiap tindakan merupakan manifestasi kesadaran yang dioperasikan melalui kehendak bebas. Tindakan adalah perwujudan dari apa yang dipikirkan dan dirasakan. Jiwa yang sadar senantiasa hadir dalam segenap tindakan dan perjumpaan dengan 'yang lain'.

Rangkaian tindakan yang bermakna merupakan langkah nyata dalam mengatasi alienasi manusia terhadap dirinya, lingkungan sesamanya maupun alam yang melanda masyarakat global sebagai ciri permasalahan akut era kontemporer. Sebagian besar manusia hidup dalam ketidakotentikan. Kebanyakan manusia menjalani hidup dalam keterpaksaan, kepura-puraan, kepalsuan, dan penuh topeng menjaga citra. Alienasi manusia menyebabkan manusia takut menghadapi kematian. Ketakutanketakutan manusia terhadap kematian sebagai akibat dari kehampaan spiritual manusia global yang mengalami krisis kemanusian, sehingga mereka hidupnya tidak otentik dan bermakna. Dunia hari ini adalah pasar raya raksasa, yang semuanya dikategorikan dalam laci-laci komoditas yang siap ditransaksikan. Semua peristiwa menjadi transaksional, begitu juga ibadah dan praktek-praktek keagamaan. Persahabatan antarmanusia -yang demikian indah dideskripsikan oleh Platohilang dan diganti dengan interaksi yang transaksional. Relasi yang terjadi adalah "Saya" dan "Ia" (I-It), bukan "Saya" dan "Engkau" (I-Thou). Dengan kata lain, manusia sudah dikutuk untuk menjadi pengada yang tidak otentik.

Gagasan panenteisme sebagai wujud Aku dalam Tuhan menyebabkan manusia akan selalu hidup otentik secara eksistensial dan bermakna dalam moral. Hidup manusia lebih otentik dan bermakna dengan tindakan-tindakan bermakna 
melalui amal kebajikan sebagai konsekuensi logis dari Aku berada dalam Tuhan. Hanya amal inilah yang bisa mengatasi kematian dan krisis kemanusia global. Aku dalam Tuhan sebagai gagasan panenteisme merupakan teologi eksistensial yang bersifat antroposentris sebagai kritik terhadap gagasan atau ideologi yang telah menjatuhkan manusia hanya sekedar robot, mesin yang tidak berkesadaran. Di sinilah munculnya kejahatan moral seperti korupsi karena manusia dalam tindakannya tidak pernah melibatkan nilai ketuhanan dalam hidup sehari-hari.

Secara teologis, Aku dalam Tuhan mencegah adanya kebebasan manusia atau indeterminisme manusia secara absolut dan pemahaman tiadanya kebebasan manusia karena adanya pemahaman deterministik absolut. Allah telah memberikan manusia kebebasan. Justeru dengan kehendak bebas itulah manusia bisa bahagia dengan sebenar-benarnya. Namun kebebasan juga membawa konsekuensi. Manusia bisa jahat karena menyalahgunakan kehendak bebasnya. Jadi, kehendak bebas memang bisa menciptakan dua kemungkinan, yakni kebaikan dan kejahatan. Namun demikian, fakta adanya kejahatan tidak kemudian membuat kehendak bebas itu harus dicabut oleh Tuhan. Jika dicabut, manusia hanya akan menjadi robot, tidak mempunyai kebebasan untuk menentukan diri sendiri, tidak bisa benar-benar bahagia.

Di sinilah, manusia secara teologis dituntut untuk bebas berbuat dalam rangka hidup otentik dan bermakna serta bertanggungjawab terhadap segala tindakan-tindakannya. Dosa, penderitaan, dan kesengsaraan merupakan akibat dari tindakan manusia yang sadar, bukan karena takdir tuhan untuk manusia. Islam sebagaimana dijelaskan dalam banyak ayatnya, memberikan konsep bahwa barang siapa berbuat baik, laki dan perempuan akan mendapat balasannya bahkan Allah dalam alQur'an menjelaskan manusia akan berubah kalau manusia merubah nasibnya sendiri. Wa al-Lāh a lam bi al-sawāb.

\section{Daftar Pustaka}

Affandi, Khozin. 2007. Fenomenologi: Pemahaman Awal PikiranPikiran Edmund Husserl. Surabaya: eLKAF. 
Bagus, Lorenz. 1991. Metafisika. Jakarta: Gramedia.

Berkhof, Hendrikus. 1986. Christian Faith: An Introduction to the Study of the Faith, revised ed., trans. Sierd Woudstra (ed.). Grand Rapids, MI: William B. Eerdmans Publishing Co. Boer, Theodore de. 1978. The Development of Husserl's Thought. London: Trans Mortinus Nijhhoff.

Buber, Martin. 1970. I and Thou. trans. W. Kauffman, Edinburgh. t.tp: tp.

Clayton, Philip. tt. "God and World", in The Cambridge Companion to Postmodern Theology, Kevin J. Vanhoozer (ed.). Cambridge: Cambridge University Press.

Cobb, John Jr. 1965. A Christian Natural Theology, Based on the Thought of Alfred North Whitehead. Philadelphia: Westminster Press.

Cobb, John Jr. and David Ray Griffin. 1977. Process Theology: An Introductory Exposition. Westminster John Knox Press.

Cooper, John W. 2006. Panenteisme The Other God of the Philosophers: From Plato to the Present. Grand Rapids-MI: Baker Academic.

Drees, Willem B. "God and Contemporary Science: Philip Clayton's Defense of Panenteisme”, Zygon, 1999.

Emmett, Dorothy. "Whitehead and Alexander", Process Studies, 1992, 137-48.

Epping, A. OFM. et. all. 1983. Filsafat ENSIE. Bandung: Jemmars.

Fakhry, Majid. 1983. A History of Islamic Philosoph. New York: Columbia University Press.

Ford, Lewis (ed.). 1973. Two Process Philosophers: Hartshorne's Encounter with Whitehead, Tuhanassee. FL: American Academy of Religion.

Gillett, Carl. "Physicalism and Panenteisme: Good News and Bad News", Faith and Philosophy. 2003.

Griffin, David Ray. 2004. "Panenteisme: A Postmodern Revelation", in In Whom We Live and Move and Have Our Being, P. Clayton and A. Peacocke (eds.). Grand Rapids-MI: William B. Eerdmans.

Hartshorne, Charles dan William Reese. 1976. Philosophers Speak of God. Chicago-London: The University of Chicago Press. 
Huijbers, Theo. 1982. Manusia mencari Allah. Jogjakarta: Kanisius. Ja'far, Suhermanto. 2003. Konsep Metafisika Moh. Iqbal. Jakarta: Tesis PPS Filsafat UI.

Moltmann, Jurgen. 1974. The Crucified God. Evanston, IL: Harper and Row.

Peursen, C.A. Van. 1988. Orientasi di Alam Filsafat, ter. Dick Hartoko. Jakarta: Gramedia.

Ritzer, George. 1996. Modern sociological Theory, 4th Edition. Singapura: the McGraw-Hill Companies Inc.

Rowe, William L. "Does panenteisme reduce to panteisme? a response to Craig", International Journal for Philosophy of Religion, 2007.

Russell, Bertrand. 1974. History of Western Philosophy. London: George Allen \& Unwin.

Sheed's. Dogmatic Theology. Volume 1-3. USA: Thomas Nelson Publisher, 1980.

Thilly, Frank. 1957. A History of Philosophy. New York: Holt, Rinehart, and Winston.

Weij, PA. Van der. 1985. Filosof-filosof Besar tentang Manusia. Jakarta: Gramedia. 